\title{
Innowacja jako narzędzie przedsiębiorczości małej firmy na przykładzie usług motoryzacyjnych
}

\begin{abstract}
Zjawisko innowacji wiąże się z pojęciem zmiany tworzącej dla każdego przedsiębiorstwa i jego klientów nową wartość. Powoduje ona wzrost konkurencyjności firmy na rynku. Zmiana ta może być postrzegana $\mathrm{w}$ dwojaki sposób: $\mathrm{z}$ jednej strony jako wynik określonych działań, a z drugiej strony jako proces obejmujący materializację pomysłu i jego upowszechnienie. Innowacje są skutkiem systematycznej pracy, wywołującej potrzebę kolejnych ulepszeń, zmian i budowania nowych zasobów. Drucker utożsamia innowacje z przedsiębiorczością i przyznaje im wiodącą rolę w rozwoju firmy, podaje również wiele przykładów innowacji, które stały się źródłem sukcesu firmy (Drucker 1992). Innowacje powinny stać się podstawowym narzędziem przedsiębiorców, decydującym o potencjale przedsiębiorczości ich firm. Wdrażanie innowacji cechuje firmy przedsiębiorcze, które spostrzegają swoje szanse, napędzają kreatywność, oceniają i szybko wdrażają pomysły. Przedsiębiorczość zatem wiąże się z koniecznością wprowadzania innowacji w całym cyklu życia firmy.
\end{abstract}

\section{Źródła inspiracji dla innowacji}

Źródła innowacji w firmach usługowych w branży usług motoryzacyjnych przedstawia ryc. 1. Głównym źródłem inspiracji jest w tym przypadku otoczenie serwisów, zarówno bliskie, jak i dalsze; innowacje mogą pochodzić również z ich wnętrza. Na innowacje w warsztatach wpływają w znacznym - wręcz globalnym stopniu - producenci samochodów i dostawcy podzespołów, producenci i dostawcy wyposażenia, narzędzi, sprzętu diagnostycznego i części zamiennych. Znaczącym źródłem pobudzania procesów innowacyjnych w serwisie samochodowym jest konkurencja w branży - warsztaty konkurencyjne. Szczególnie ważnym źródłem innowacji są odbiorcy usług motoryzacyjnych oraz użytkownicy samochodów.

Wewnętrznym źródłem innowacji w warsztacie samochodowym sąjego pracownicy i kadra. Dla kadry i pracowników serwisu samochodowego podstawowym źródłem kreowania innowacji jest wiedza - zdobywana na szkoleniach, kursach, targach i wystawach. Źródła wiedzy to prasa motoryzacyjna, raporty i opracowania ośrodków naukowo-badawczych, literatura fachowa, bazy danych oraz obserwacje rynku polskiego i zagranicznego. Wiedza przyczynia się do trwałego powiększania niematerialnych zasobów każdego warsztatu samochodowego.

Innowacje są również inspirowane uwarunkowaniami prawnymi, ekonomicznymi i politycznymi, w których działają warsztaty samochodowe. Po przystąpieniu Polski do Unii Europejskiej powstały warunki swobodnego podróżowania po krajach Unii, nawiązywania kontaktów biznesowych i przepływu informacji. Akcesja do Unii spowodowała zwiększenie importu używanych i tanich samochodów, co z kolei wpłynęło na zmianę struktury samochodowych usług naprawczych i serwisowych oraz na warunki działania zakładów usługowych. Znacznie zwiększyło się zapotrzebowanie na usługi blacharskie, naprawy mechaniczne, usługi złomowania itd. 
Dyrektywy unijne dotyczące sprzedaży samochodów i części samochodowych oraz usług naprawczych wprowadziły nowe wymagania dla zakładów motoryzacyjnych na terenie Unii Europejskiej (Konieczny 2004).

Ryc. 1. Zewnętrzne i wewnętrzne źródła kreowania innowacji w warsztacie samochodowym

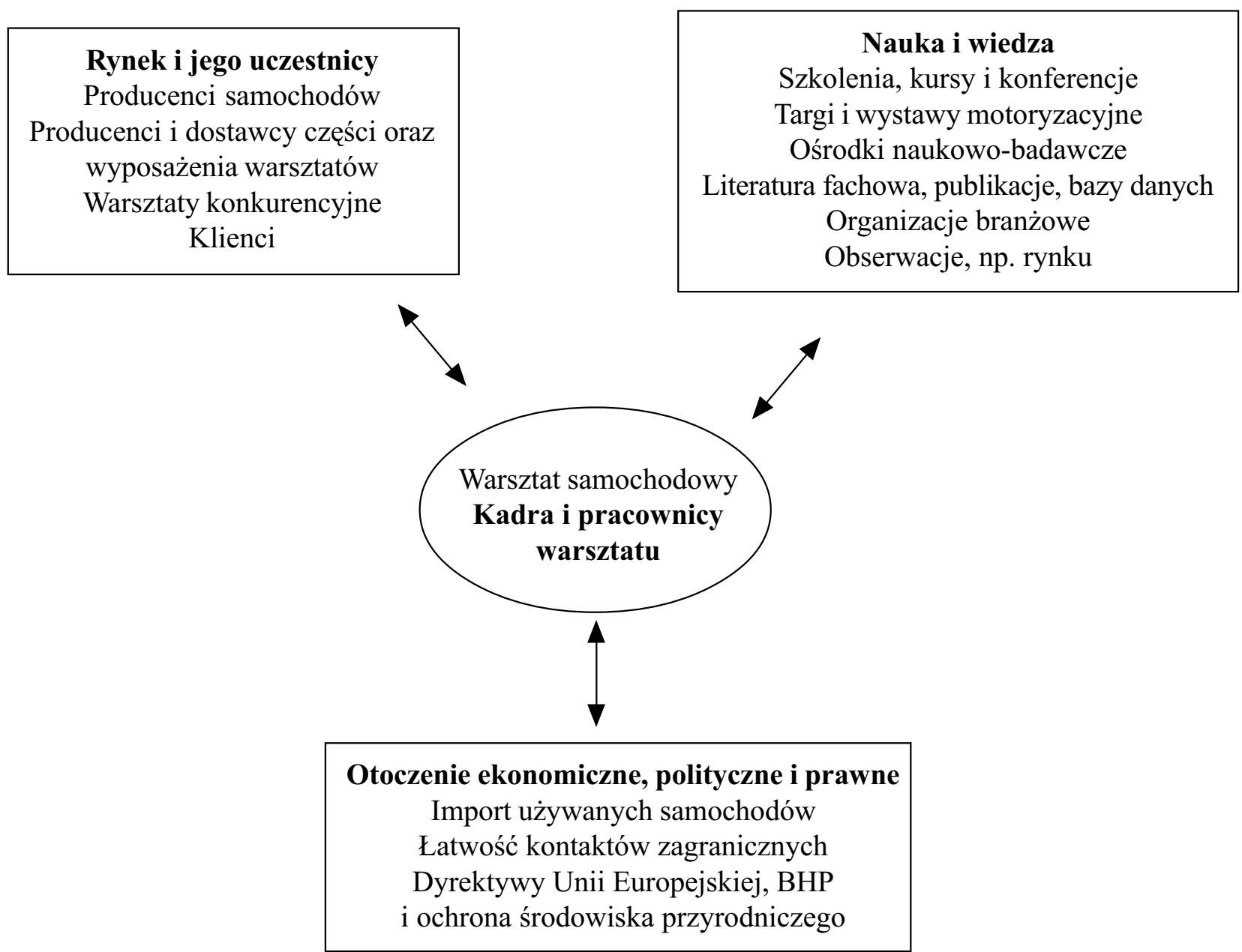

Źródło: opracowanie własne

Istotne znaczenie dla kreowania innowacji w warsztatach samochodowych miało przyjęcie prawa unijnego dotyczącego ochrony środowiska przyrodniczego oraz bezpieczeństwa i higieny pracy.

Różnorodność źródeł innowacji może wpływać na pomysły i kreatywność we wdrażaniu zmian w usługach motoryzacyjnych oraz w pozyskiwaniu źródeł finansowania innowacji. Takie wielowymiarowe ujęcie źródeł innowacji może sprzyjać pobudzaniu innowacji w wielu obszarach działalności usługowej w branży motoryzacyjnej.

\section{Rodzaje innowacji w usługach motoryzacyjnych}

W usługach motoryzacyjnych można wyróżnić innowacje: produktowe, technologiczne, ekologiczne i w zarządzaniu (ryc. 2). Serwisy samochodowe generują przeważnie innowacje o małej skali, polegające zwykle na zakupach wyposażenia i naśladowaniu, tzw. imitacje. Innowacje o dużej skali powstają przede wszystkim u producentów samochodów i dostawców podzespołów.

Innowacje produktowe mają w gospodarce rynkowej podstawowe znaczenie (Pomykalski 2001). Wiąże się to z faktem, na który zwrócił uwagę J. Schumpeter, że współczesna forma konkurencji 
to konkurencja z nowymi produktami, a nie tylko konkurencja cenowa (Schumpeter 1960, s. 164). Ma to szczególnie znaczenie w branży motoryzacyjnej, gdzie wprowadzanie nowych rozwiązań konstrukcyjnych w samochodach implikuje innowacje w usługach motoryzacyjnych. Przykładem takich relacji może być wprowadzenie podzespołów elektronicznych w pojazdach samochodowych, które wywołało konieczność wprowadzenia nowych specjalności w usługach motoryzacyjnych. Wzrost znaczenia ekologii spowodował zmianę w konstrukcji samochodów, zmiany w przyrządach diagnostycznych, powstały nowe, specjalistyczne narzędzia oraz nowe procedury obsługowo-naprawcze. Innowacje produktowe w tej branży to przede wszystkim nowe usługi poszerzające ofertę i przynoszące korzyści zarówno serwisowi, jak i klientom. Najwięcej innowacji tego rodzaju powstaje w takich dziedzinach funkcjonowania warsztatu, jak serwis samochodu i obsługa klienta, handel oraz usługi specjalistyczne (tab. 1).

Ryc. 2. Wpływ innowacji na zmiany w przedsiębiorstwie w ujęciu rodzajowym

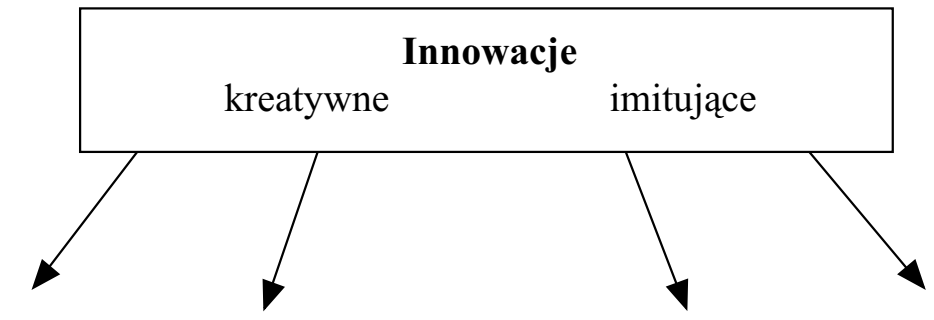

\begin{tabular}{|c|}
\hline Produktowe \\
nowy produkt \\
(usługa) nieznany \\
na rynku lub już \\
znany, ale o zmie- \\
nionych właściwo- \\
ściach użytkowych
\end{tabular}

\begin{tabular}{|c|}
\hline Technologiczne \\
całkowita lub \\
częściowa zmiana \\
w strukturze \\
i liczbie czynni- \\
ków wytwórczych \\
\hline
\end{tabular}

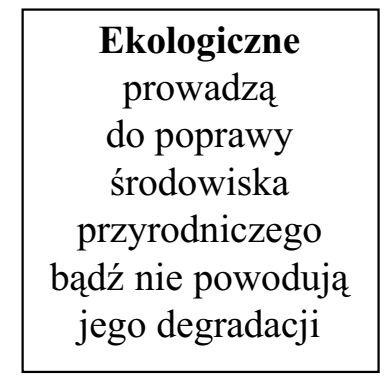

Rodzaje innowacji

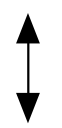

Korzyści dla przedsiębiorstwa z wprowadzenia innowacji

$$
\begin{gathered}
\text { Zwiększenie lub } \\
\text { utrzymanie udziału } \\
\text { w rynku }
\end{gathered}
$$

\section{Udoskonalanie zarządzania}
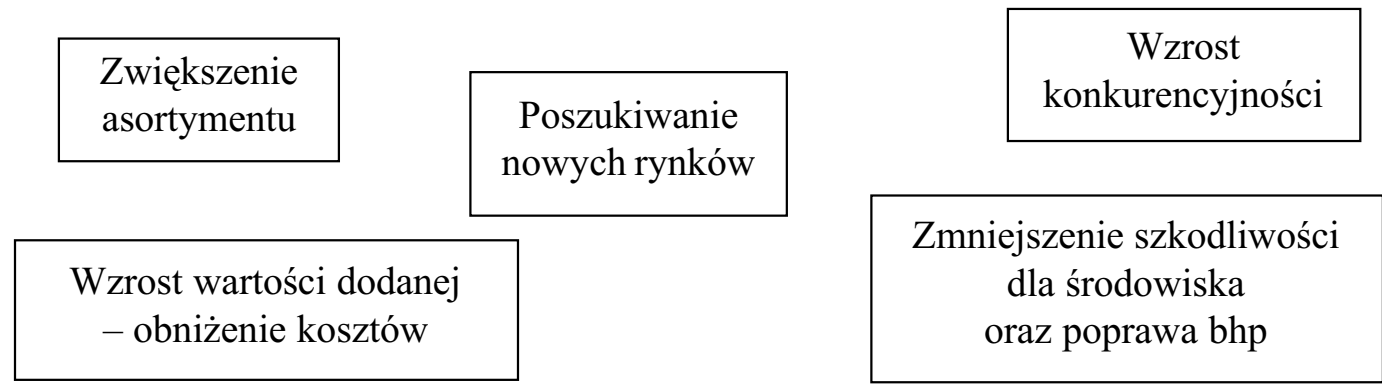

Źródło: opracowanie własne na podstawie: A. Pomykalski, Zarządzanie innowacjami, PWN, Warszawa-Łódź 2001, s. 19; L. Białoń, Przedsiębiorstwo [w:] S. Marciniak (red.), Makro i mikroekonomia. Podstawowe problemy, Wydawnictwo Naukowe PWN, Warszawa 1998, s. 238. 
Tab. 1. Przykłady korzyści dla sektora i klientów z wprowadzenia innowacji produktowych w niezależnych warsztatach

\begin{tabular}{|c|c|c|}
\hline \multicolumn{3}{|c|}{ Innowacje produktowe } \\
\hline Dziedzina & Przykłady & Korzyści dla sektora i klientów \\
\hline $\begin{array}{l}\text { 1. Serwis, } \\
\text { obsługa } \\
\text { klienta, } \\
\text { produkcja } \\
\text { narzędzi } \\
\text { i urzą- } \\
\text { dzeń } \\
\text { warszta- } \\
\text { towych }\end{array}$ & $\begin{array}{l}\text { Obsługa nowych marek, diagnostyka } \\
\text { komputerowa, pomoc drogowa, naprawa } \\
\text { w miejscu awarii, bezpłatne holowanie do } \\
\text { serwisu, montaż akcesoriów, bezpłatne } \\
\text { mycie i czyszczenie samochodu po ser- } \\
\text { wisie, biuro obsługi i poczekalnia dla } \\
\text { klienta, rejestr historii napraw - kartoteki } \\
\text { dla klientów, bezgotówkowe i kredytowe } \\
\text { formy rozliczeń, bezpłatna kontrola stanu } \\
\text { technicznego, odprowadzenie/odbiór sa- } \\
\text { mochodu do/z domu klienta, wypożycze- } \\
\text { nie samochodu zastępczego, kontrolne } \\
\text { telefony do klienta po kilku dniach od na- } \\
\text { prawy, usługa ,zrób sam”, specjalne wa- } \\
\text { runki serwisowania, produkcja urządzeń } \\
\text { do prostowania nadwozi samochodowych, } \\
\text { produkcja narzędzi specjalistycznych. }\end{array}$ & $\begin{array}{l}\text { Rozszerzenie asortymentu usług i zwięk- } \\
\text { szenie obszaru działania warsztatu, wpro- } \\
\text { wadzanie usług zaspokajających nawet naj- } \\
\text { bardziej nieoczekiwane potrzeby klientów, } \\
\text { np. udostępnienie klientowi stanowiska, } \\
\text { narzędzi i fachowej pomocy, tak aby mógł } \\
\text { sam wykonać obsługę lub naprawę samo- } \\
\text { chodu (,zrób sam”), zwalnianie klienta } \\
\text { z konieczności zapamiętywania informacji } \\
\text { o historii serwisowania, racjonalne zago- } \\
\text { spodarowywanie pozostałości po naprawie, } \\
\text { niesienie wszechstronnej pomocy kliento- } \\
\text { wi przy sprzedaży i zakupie samochodu, } \\
\text { wymuszanie na konkurencji swoistego wy- } \\
\text { ścigu asortymentowego w świadczeniu róż- } \\
\text { norodnych usług specjalistycznych, czego } \\
\text { przykładem są firmy zajmujące się tunin- }\end{array}$ \\
\hline 2. Handel & $\begin{array}{l}\text { Skup i sprzedaż używanych zespołów } \\
\text { i części, pośrednictwo w sprzedaży uży- } \\
\text { wanych samochodów, doradztwo tech- } \\
\text { niczne, bezpłatne wyceny, formalności } \\
\text { związane z ubezpieczeniem. }\end{array}$ & $\begin{array}{l}\text { giem lub obsługujące ogumienie, ktore } \\
\text { również przechowują opony klientów. }\end{array}$ \\
\hline $\begin{array}{l}\text { 3. Usługi } \\
\text { specjali- } \\
\text { styczne }\end{array}$ & $\begin{array}{l}\text { Obsługa i naprawa: klimatyzacji, instalacji } \\
\text { gazowych, systemów bezpieczeństwa, } \\
\text { układów zasilania i ogumienia, pompowa- } \\
\text { nie kół azotem, przechowywanie opon } \\
\text { klientów, mycie i konserwacja samochodu, } \\
\text { tuning. }\end{array}$ & \\
\hline
\end{tabular}

Źródło: opracowanie własne

Niezależne warsztaty naprawy samochodów w latach 2001-2004 znacznie rozszerzyły zakres usług i oferty dla klienta. Do najczęściej proponowanych innowacji w zakresie obsługi klienta należały:

- zwiększenie liczby obsługiwanych marek samochodów;

- wprowadzenie systemów nowoczesnej diagnostyki komputerowej;

- wprowadzenie szerszego asortymentu montowanych akcesoriów bez konieczności magazynowania - zamawianie akcesoriów przez internet;

- wprowadzenie rejestru historii obsługi i naprawy samochodu;

- poszerzenie zakresu pomocy drogowej;

- wprowadzenie systemów nowoczesnej diagnostyki;

- przeprowadzanie drobnych napraw w miejscu powstania awarii;

- poprawa warunków oczekiwania na naprawę. 
Niektóre z tych zmian są uznawane za standard, zwłaszcza w dużych warsztatach wielostanowiskowych i w warsztatach autoryzowanych, natomiast w małych serwisach niezależnych, które stanowią większość, zalicza się je do działań innowacyjnych, gdyż nadal wiele z nich występuje sporadycznie, np. diagnostyka komputerowa, rejestr historii napraw czy odpowiednia poczekalnia dla klientów.

Przykładem produktu spełniającego nawet najbardziej nieoczekiwane potrzeby klientów, a dotychczas występującego sporadycznie w serwisach, jest usługa „zrób sam”. Polega ona na udostępnieniu klientowi stanowiska, narzędzi i fachowej pomocy, tak aby mógł sam wykonać obsługę lub prostą naprawę w swoim samochodzie, np. wymianę oleju, klocków hamulcowych. Ma to najczęściej miejsce w niektórych firmach flotowych, w których większość prac serwisowych i drobnych napraw wykonują sami kierowcy (P. Szreter, „FlotaAutoBiznes”, 4/2004, s. 22). Usługa ta jest tańsza i klientowi (nieufnemu lub mającemu upodobania manualne) daje większe poczucie prawidłowości jej wykonania. Inną usługą wprowadzoną w ostatnich latach jest możliwość śledzenia przez klienta przebiegu prac przy samochodzie bezpośrednio albo przy użyciu kamer zamontowanych na stanowiskach. Obraz jest najczęściej odtwarzany w poczekalni dla klienta, a bardziej innowacyjne serwisy przesyłają obraz siecią internetową. Ma to umożliwić klientowi ciagłą obserwację naprawy bez względu na jego miejsce pobytu.

Oprócz działalności typowo usługowej niektóre serwisy prowadzą działalność wytwórcza, polegająca na produkowaniu narzędzi lub specjalistycznych urządzeń dla potrzeb innych warsztatów z branży. Przykładem jest warsztat Automet w Słubicach (woj. mazowieckie), który oprócz wykonywania prac typowo blacharskich produkuje urządzenia do prostowania karoserii samochodowych. Warsztaty Zespołu Szkół Samochodowych w Radomiu wytwarzają narzędzia specjalistyczne dla warsztatów naprawiających samochody. Niekiedy produkty ubocznej działalności warsztatów skutecznie konkurują zarówno ceną, jak i jakością z narzędziami firm markowych.

Innowacje w handlu polegają głównie na łączeniu usług naprawczych ze sprzedażą części i akcesoriów samochodowych, np. prowadzenie skupu i sprzedaży używanych zespołów lub części, niekiedy regenerowanych na miejscu w warsztacie. Prowadzone są również usługi pośrednictwa sprzedaży częściami samochodowymi i samochodami. Nową formą usług handlowych w warsztatach samochodowych w Polsce jest doradztwo handlowe przy sprzedaży samochodów (standard w krajach UE).

Rozszerzanie oferty usług naprawczych w warsztatach samochodowych wiąże się z dużymi nakładami finansowymi i koniecznością zatrudnienia wysoko wykwalifikowanego personelu. Koszty wprowadzania innowacji tego rodzaju ograniczają możliwości wdrożenia wielu innowacji jednocześnie, co z kolei prowadzi do specjalizacji warsztatu. Badania własne autora potwierdziły to zjawisko - ze wskazaniem najczęściej wdrażanych innowacji:

- usługi w zakresie obsługi i naprawy układów zasilania paliwem;

- usługi w instalowaniu i serwisowaniu urządzeń klimatyzacji;

- montaż instalacji gazowych;

- wymiana i konserwacja ogumienia;

- mycie i konserwacja samochodów;

- tuning.

Innowacja technologiczna zwykle prowadzi do innowacji produktowej (Marciniak, 1998, s. 238). W przypadku innowacji na rynku usług, a zatem i usług motoryzacyjnych, innowacja produktu i innowacja technologii łączą się i mogą być jednocześnie uznane zarówno za innowację produktowa, jak i technologiczną. Innowacje technologiczne w warsztatach samochodowych przejawiają się zmianami w wyposażeniu i w procesach obsługowo-naprawczych, obniżają koszty usług i zwiększają ich efektywność. W dziedzinie wyposażenia zmiany polegają 
na wprowadzaniu do serwisu nowoczesnych narzędzi i sprzętu diagnostycznego, sieci informatycznej, urządzeń specjalistycznych oraz na tworzeniu nowych stanowisk obsługowo-naprawczych. Zmiany w wyposażeniu serwisu zarówno w dziedzinie narzędzi ręcznych i mechanicznych oraz w dziedzinie sprzętu diagnostycznego stwarzają serwisom nowe możliwości. Przysparzają korzyści ekonomicznych, ergonomicznych, technologicznych i poprawiają warunki bezpieczeństwa i higieny pracy, co prowadzi do poprawy konkurencyjności serwisu na rynku. Korzyści ekonomiczne polegają na zwiększeniu wydajności pracy i zakresu usług, co rekompensuje wydatki na zakup nowoczesnych narzędzi i sprzętu. Korzyści technologiczne wpływają także na konkurencyjność, gdyż zapewniają trafną diagnozę usterek i właściwą jakość naprawy samochodu, którą jest łatwiej uzyskać za pomocą narzędzi zmechanizowanych. Efektem ergonomicznym jest to, że mimo wielokrotnie wyższej wydajności wysiłek fizyczny mechanika wykorzystującego nowoczesne narzędzia i sprzęt diagnostyczny znacznie się zmniejsza. W zamian za te korzyści mechanik samochodowy w większym stopniu niż dotychczas musi wykorzystywać wiedzę o budowie i obsłudze współczesnych samochodów.

Tab. 2. Przykłady korzyści dla sektora i klientów z wprowadzenia innowacji technologicznych w niezależnych warsztatach

\begin{tabular}{|c|c|c|}
\hline \multicolumn{3}{|c|}{ Innowacje technologiczne } \\
\hline Dziedzina & Przykłady & Korzyści dla sektora i klientów \\
\hline $\begin{array}{l}\text { 1. Wyposażenie } \\
\text { Nowe narzędzia } \\
\text { i sprzęt zastępują } \\
\text { lub uzupełniają } \\
\text { dotychczasowe. }\end{array}$ & $\begin{array}{l}\text { Nowoczesne narzędzia ręczne i me- } \\
\text { chaniczne, nowoczesny sprzęt diagno- } \\
\text { styczny, sieć informatyczna, urządze- } \\
\text { nia specjalistyczne, nowe stanowiska } \\
\text { obsługowo-naprawcze. }\end{array}$ & \multirow{2}{*}{$\begin{array}{l}\text { Wzbogacanie asortymentu narzędzi } \\
\text { i wymiana ich na bardziej trwałe, do- } \\
\text { kładne, skuteczne, poręczne i uniwer- } \\
\text { salne zmniejsza ryzyko zatruć mecha- } \\
\text { ników (np. urządzenie niedopuszcza- } \\
\text { jące do rozprzestrzeniania się toksycz- } \\
\text { nej mgły przy kontroli wtryskiwaczy), } \\
\text { zastępowanie narzędzi ręcznych me- } \\
\text { chanicznymi to oszczędność czasu } \\
\text { i wzrost wydajności pracy mechanika, } \\
\text { profesjonalne urządzenia diagnostycz- } \\
\text { ne upraszczają wyszukiwanie usterek, } \\
\text { zmniejszają pracochłonność obsługi } \\
\text { samochodu i warunkują rozwój warsz- } \\
\text { tatu (utrzymanie się na rynku), specjali- } \\
\text { styczny sprzęt poszerza zakres świadczo- } \\
\text { nych usług, metoda wymiany zespołów } \\
\text { skraca czas przestoju samochodu w war- } \\
\text { sztacie. }\end{array}$} \\
\hline $\begin{array}{l}\text { 2. Procesy } \\
\text { obsługowo- } \\
\quad \text {-naprawcze }\end{array}$ & $\begin{array}{l}\text { Innowacje w procesach obsługi i napraw, } \\
\text { np. będace konsekwencją udziału elek- } \\
\text { troniki i dodatkowego wyposażenia sa- } \\
\text { mochodu; innowacje w metodach, } \\
\text { np. bezinwazyjne metody renowacji la- } \\
\text { kierów samochodowych, wymiany ca- } \\
\text { łych zespołów, mechanizacja poszcze- } \\
\text { gólnych czynności. }\end{array}$ & \\
\hline
\end{tabular}

Źródło: opracowanie własne

Do sektora warsztatów samochodowych należą też firmy wielostanowiskowe, które oprócz typowej obsługi i naprawy samochodu świadczą usługi specjalistyczne, np. naprawy ogumienia, blacharskie, lakiernicze, mycie samochodów, naprawy przekładni automatycznych. W małych warsztatach usługi specjalistyczne przesądzają o profilu działalności. Wyposażenie 
warsztatów świadczących usługi specjalistyczne charakteryzuje się dużym zawansowaniem technicznym i inwestycyjnym. Innowacje w wyposażeniu umożliwiają poszerzenie asortymentu usług i poprawę ich jakości.

Procesy obsługowo-naprawcze samochodów określają porządek prac lub operacji wykonywanych zgodnie z wymogami technicznymi (inaczej mówiąc, wszystko, co się dzieje w warsztacie, czyli co i w jakiej kolejności się wykonuje). Innowacje w procesach obsługi i napraw są konsekwencją postępu w konstrukcji samochodu, dużego w nim udziału elektroniki i dodatkowego wyposażenia. Innowacje w technologiach - rozumianych jako sposoby i metody napraw - polegają na skracaniu czasu postoju samochodu w serwisie. Przykładem jest mechanizacja niektórych czynności obsługowych lub w co raz większym stopniu stosowana metoda wymiany całych zespołów. Innym przykładem innowacji jest renowacja lakierów samochodowych, którą można wykonać tradycyjnymi metodami: matowania, polerowania lub z zastosowaniem odpowiednich środków polerskich i polerowania z użyciem waty bawełnianej (Majchrzak, „Świat Motoryzacji”, 4/2005, s. 36).

Jeśli innowacja produktowa i technologiczna w oczywisty sposób prowadzi do poprawy ochrony środowiska przyrodniczego bądź nie powoduje jego degradacji, to może zostać uznana za innowację ekologiczną. W usługach motoryzacyjnych innowacje ekologiczne to takie, które chronią środowisko przyrodnicze przed szkodliwym wpływem pozostałości procesu obsługi bądź naprawy samochodów, minimalizują powstające odpady, np. poprzez ich utylizację. W warsztatach samochodowych powstają one m.in. w dziedzinie recyklingu i wyposażenia. W Polsce najbardziej popularna jest produktowa forma recyklingu, polegająca na skupowaniu samochodów powypadkowych, najczęściej w dobrym stanie technicznym, których sprawne technicznie elementy oraz podzespoły po demontażu i segregacji znajdują nowych nabywców. Warunkami dużej skuteczności recyklingu produktów są odpowiednia kultura techniczna i jakość demontażu złomowanych pojazdów (Chłopek, 2002, s. 146). Niektóre warsztaty stosują recykling energii, polegający na spalaniu przepracowanych olejów silnikowych i ogrzewaniu tym sposobem pomieszczeń lub magazynu. Jest to dla warsztatu bezpłatne źródło energii cieplnej pod warunkiem, że wykorzystuje się przystosowane do tego celu piece. Szczególnie dużo innowacji ekologicznych w warsztatach samochodowych powstaje w dziedzinie regeneracji używanych części lub kompletnych zespołów samochodu (Włodarczyk, Janczewski, „Przegląd Organizacji”, 1/2005, s. 23 i 24). Te części i zespoły pochodzą z odzysku, z własnego skupu lub ze specjalistycznych stacji demontażu pojazdów. Wielu użytkowników, w tym flotowych, jest zainteresowanych korzystaniem z tańszych i regenerowanych części, jeśli tylko jest to możliwe i nie pogorszy właściwości jezdnych samochodu, a zwłaszcza jego bezpieczeństwa (,Flota Autobiznes", 4/2004, s. 27). Na poprawę środowiska przyrodniczego mają również wpływ odpowiednie wyposażenie serwisu i stosowane w nim procesy obsługowo-naprawcze, np. nowoczesne kabiny lakiernicze (Majchrzak, „Świat Motoryzacji”, 3/2005, s. 36), niskociśnieniowe pistolety (Kelar, „Świat Motoryzacji”, 9/2004, s. 36), regeneratory rozpuszczalników (Majchrzak, „Świat Motoryzacji”, 6/2004, s. 46-48), myjnie do pistoletów (Majchrzak, „Świat Motoryzacji”, 12/2003, s. 28 i 29), nierozpowszechnione w serwisach lakiernictwo wodne (Kelar, „Świat Motoryzacji”, 3/2005, s. 34), stosowanie urządzeń izolujących od środowiska przyrodniczego proces wymiany płynów eksploatacyjnych i oczyszczania lub mycia części i ich zespołów. Jak wynika z badań, w warsztatach stosowane są różne metody wymiany płynów i mycia części z zastosowaniem najrozmaitszego sprzętu. Przy oczyszczaniu i myciu części nierzadko korzysta się ze środków chemicznych, które są szkodliwe dla zdrowia i środowiska, ponadto stanowią olbrzymie zagrożenie pożarowe. 
Tab. 3. Przykłady korzyści dla sektora i klientów z wprowadzenia innowacji ekologicznych w niezależnych warsztatach

\begin{tabular}{|c|c|c|}
\hline \multicolumn{3}{|c|}{ Innowacje ekologiczne } \\
\hline Dziedzina & Przykłady & Korzyści dla sektora i klientów \\
\hline 1. Recykling & $\begin{array}{l}\text { Regeneracja części i zespołów samo- } \\
\text { chodu, wykorzystanie do ogrzewania } \\
\text { warsztatu zużytych olejów mineral- } \\
\text { nych. }\end{array}$ & \multirow{2}{*}{$\begin{array}{l}\text { Wtórne przetwarzanie zespołów lub } \\
\text { części (recykling) jako działalność } \\
\text { uboczna lub specjalizacja warsztatu, } \\
\text { odzyskiwanie i regenerowanie części } \\
\text { obniżające ceny usług, skracanie cza- } \\
\text { su usługi, wskazywanie konieczności } \\
\text { przestrzegania zasad ochrony środowi- } \\
\text { ska przyrodniczego przy projektowaniu } \\
\text { technologii obsługi i napraw, zachęcanie } \\
\text { producentów w branży do wprowadzania } \\
\text { technologii i produktów poprawiają- } \\
\text { cych stan środowiska przyrodniczego } \\
\text { bądź niepowodujących jego dalszej } \\
\text { degradacji. }\end{array}$} \\
\hline $\begin{array}{l}\text { 2. Wyposażenie } \\
\text { i procesy }\end{array}$ & $\begin{array}{l}\text { Nowoczesne lakiernictwo, wymiana cze- } \\
\text { ści i zespołów wtedy, gdy to jest naprawdę } \\
\text { konieczne, a nie dlatego, że tak przewi- } \\
\text { duje plan serwisowania, urządzenia izo- } \\
\text { lujące od środowiska przyrodniczego pro- } \\
\text { ces wymiany płynów eksploatacyjnych, } \\
\text { np.: wymiana oleju lub płynu chłodzące- } \\
\text { go zachowująca obieg zamknięty zarówno } \\
\text { płynu usuwanego, jak i nowego, urzadzenia } \\
\text { do mycia czéści w obiegu zamkniętym, } \\
\text { używanie środków o małej szkodliwości } \\
\text { dla środowiska, np. przy myciu, klejeniu. }\end{array}$ & \\
\hline
\end{tabular}

Źródło: opracowanie własne

Niektórzy producenci ustalają plany serwisowania samochodów niejako „na wyrost”, przezornie skracając resursy obsługowe, co również nie sprzyja ochronie środowiska. Klasycznym przykładem tego są zbyt częste wymiany świec zapłonowych, zalecane w niektórych instrukcjach obsługi, chociaż powszechnie wiadomo, że obecnie produkowane świece zapłonowe mają dużą trwałość i mechanik z łatwością dokona oceny stanu technicznego. Jeżeli nie ma to istotnego wpływu na bezpieczeństwo użytkowania samochodu, to warto dokonywać możliwych korekt, wykorzystując bogate doświadczenia warsztatów. Do innowacji ekologicznych należy również zaliczyć używanie przez warsztaty środków o małej szkodliwości dla środowiska przyrodniczego, takich jak kleje, środki myjące czy różnego rodzaju pasty. Powinno to zachęcić również producentów w branży do wprowadzania technologii i produktów chroniących środowisko przyrodnicze bądź niepowodujących jego dalszej degradacji.

Innowacje w zarządzaniu i organizacji pracy mogą dotyczyć całej firmy albo jej części. Występują one zarówno w planowaniu i organizowaniu, jak i w kierowaniu, komunikacji i kontroli. Najważniejsze obszary dla innowacji tego typu to:

- analiza otoczenia poprzez rozpoznanie uczestników rynku, segmentację klientów;

- stosowanie instrumentów tzw. marketingu mix;

- pozyskiwanie źródeł finansowania, m.in. z funduszy Unii Europejskiej;

- nowoczesne sposoby zarządzania, w tym zarządzanie wiedza, wdrażanie clientingu;

- wykorzystanie IT w procesach zarządzania;

- stymulowanie i wykorzystywanie potencjału innowacyjnego pracowników;

- doskonalenie jakości usług poprzez wdrażanie systemów zarządzania jakością z grupy ISO;

- budowanie nowoczesnych struktur organizacyjnych poprzez tworzenie tzw. struktur sieciowych. 
Współczesne warsztaty zmieniają sposoby komunikowania się z otoczeniem, budują trwałe relacje z klientami oraz prowadzą badania i analizy rynku. W tych działaniach uzyskują wsparcie dystrybutorów części (np. Bosch, Gutmann). Budowanie poprawnych relacji z klientami, wiązanie ich z firmą za pomocą stałych instrumentów wydziela stałą grupę klientów i jest coraz szerzej stosowane w małych firmach usługowych z branży samochodowej. Promocje i reklama w mediach, bezpłatne usługi, np. niektóre przeglądy ${ }^{1}$, czynią warsztat jeszcze bardziej widocznym w środowisku i zachęcaja grupę niestałych klientów do bliższego związania się z serwisem.

Tab. 4. Przykłady wprowadzenia innowacji w zakresie organizacji i zarządzania w niezależnych warsztatach

\begin{tabular}{|c|c|c|}
\hline \multicolumn{3}{|c|}{ Innowacje w zakresie organizacji i zarządzania } \\
\hline Dziedzina & Przykłady & Korzyści dla sektora i klientów \\
\hline $\begin{array}{l}\text { 1. Współpraca } \\
\text { z otoczeniem }\end{array}$ & $\begin{array}{l}\text { Tworzenie sieci i wspólnych przedsię- } \\
\text { wzięć, zmiany w zakresie organizacji } \\
\text { i sposobu zaopatrywania w części, zmia- } \\
\text { ny w sposobach komunikowania się } \\
\text { z dostawcami i klientami, budowanie } \\
\text { trwałych więzi z klientami, obserwacje } \\
\text { i analiza otoczenia, np. badania rynku. }\end{array}$ & \multirow{7}{*}{$\begin{array}{l}\text { Wspólne działania podkreślają obec- } \\
\text { ność firmy na rynku, ułatwiają zaopa- } \\
\text { trywanie w cześci i narzędzia specjali- } \\
\text { styczne oraz pozyskiwanie środków na } \\
\text { rozwój, szkolą pracowników i mene- } \\
\text { dżerów warsztatów, podnosza jakość } \\
\text { usług i tym samym zwiększają konku- } \\
\text { rencyjność warsztatów; zaniechanie } \\
\text { przez niektóre warsztaty nastawienia } \\
\text { na przetrwanie i intuicyjnego kierowa- } \\
\text { nia firmá na korzyść nowoczesnych } \\
\text { sposobów zarządzania wywołuje na- } \\
\text { śladownictwo w sektorze; wykorzysta- } \\
\text { nie możliwości komputera, w tym in- } \\
\text { ternetu, nie tylko przyspiesza diagno- } \\
\text { zowanie samochodu i wykrywanie } \\
\text { usterek, ale także skraca czas komuni- } \\
\text { kacji warsztatu z otoczeniem, uprasz- } \\
\text { cza pracochłonne czynności związane } \\
\text { z ewidencją w firmie, prowadzenie } \\
\text { magazynów, kartoteki klientów, roz- } \\
\text { liczanie się z klientami, urzędem skar- } \\
\text { bowym, ZUS-em i wiele innych; } \\
\text { wprowadzanie systemów jakości, po- } \\
\text { zyskiwanie certyfikatów i ubieganie } \\
\text { się u producentów o autoryzację } \\
\text { zwiększa szanse i możliwości usługo- } \\
\text { we serwisów, a tym samym daje szan- } \\
\text { sę na dalsze utrzymanie się warsztatu } \\
\text { na rynku. }\end{array}$} \\
\hline $\begin{array}{l}\text { 2. Promocja } \\
\text { i reklama firmy }\end{array}$ & $\begin{array}{l}\text { Bezpłatne przeglądy, bezpłatne holowa- } \\
\text { nie, reklama firmy w środkach masowe- } \\
\text { go przekazu, własna strona internetowa. }\end{array}$ & \\
\hline $\begin{array}{l}\text { 3. Pozyskanie } \\
\text { źródeł } \\
\text { finansowania }\end{array}$ & $\begin{array}{l}\text { Wykorzystanie środków unijnych, fundu- } \\
\text { sze mikro. }\end{array}$ & \\
\hline $\begin{array}{l}\text { 4. Sposoby } \\
\text { zarządzania }\end{array}$ & $\begin{array}{l}\text { Zarządzanie strategiczne firmą, zarządza- } \\
\text { nie przez cele. }\end{array}$ & \\
\hline $\begin{array}{l}\text { 5. Stymulowanie } \\
\text { i wykorzystanie } \\
\text { potencjału } \\
\text { innowacyjnego } \\
\text { pracowników }\end{array}$ & $\begin{array}{l}\text { Ciagłe podnoszenie kwalifikacji - kształ- } \\
\text { cenie ustawiczne, szkolenia, ekwiwa- } \\
\text { lentne wynagrodzenie. }\end{array}$ & \\
\hline $\begin{array}{l}\text { 6. Technologie } \\
\text { informatyczne }\end{array}$ & $\begin{array}{l}\text { Wykorzystaniemożliwości komputera we } \\
\text { wszystkich dziedzinach funkcjonowania } \\
\text { serwisu. }\end{array}$ & \\
\hline $\begin{array}{l}\text { 7. Doskonalenie } \\
\text { jakości }\end{array}$ & $\begin{array}{l}\text { Certyfikaty, systemy jakości, autoryzacje } \\
\text { producenta. }\end{array}$ & \\
\hline
\end{tabular}

Źródło: opracowanie własne

\footnotetext{
${ }^{1}$ Przykładem może być akcja serwisowa firmy Warsaw Truck Center, polegająca na sprawdzaniu za symboliczną złotówkę technicznego stanu pojazdu po sezonie zimowym [w:] Kontrola za 1 zl, „Świat Motoryzacji”, 4/2005, s. 5.
} 
Wspólne działania z innymi firmami, także konkurencyjnymi, nie tylko podkreślają obecność warsztatu na rynku, ale ułatwiają zaopatrzenie w części i narzędzia specjalistyczne, pozyskiwanie środków finansowych na zakup wyposażenia oraz prowadzenie wspólnych szkoleń kadry i pracowników. Wprowadzone od niedawna w Unii Europejskiej i w Polsce zmiany prawne GVO (Konieczny, 2004) sprzyjają wzmocnieniu mechanizmów konsolidacji w serwisach samochodowych.

Zarówno badania własne autora, jak i badania A.R. Sklorza dotyczące scenariuszy konsolidacji (,Świat Motoryzacji”, 6/2004, s. 40 i 41; 9/2004, s. 38 i 39) potwierdzają, że najbardziej korzystna dla małych firm naprawczych jest kooperacja w sieci, która przyczynia się do podnoszenia jakości usług i konkurencyjności warsztatów. W zarządzaniu firmą warsztaty coraz częściej odchodzą od intuicyjnej metody zarządzania, połączonej z tzw. dryfowaniem w kierunku opracowywania strategii firmy i wyznaczania celów marketingowych. Badania własne autora dotyczące innowacji organizacyjnych w niezależnych warsztatach samochodowych są zgodne z opiniami uczestników konferencji Strategie innowacji (SGH, 2003), że obecnie co trzecie małe przedsiębiorstwo w Polsce prowadzi działania stymulujące innowacyjność (ryc. 3).

Wdrażanie technologii informatycznych i wykorzystywanie możliwości komputera we wszystkich dziedzinach funkcjonowania warsztatu to również przykłady innowacji w warsztatach samochodowych. Wykorzystywanie możliwości komputera i narzędzi internetu przyspiesza diagnozowanie samochodu i wykrywanie w nim usterek, skraca czas komunikacji warsztatu $\mathrm{z}$ otoczeniem, upraszcza pracochłonne czynności związane $\mathrm{z}$ ewidencją $\mathrm{w}$ firmie, np. prowadzeniem magazynów, rozliczaniem się z klientami, urzędem skarbowym lub zakładem ubezpieczeń społecznych. Jeszcze w 2003 r., jak wynika z badań autora, zaledwie 40\% warsztatów dysponowało komputerem, w 2004 r. komputer posiadało już około 55\% badanych warsztatów. Potwierdza to również firma MotoFocus (Gołąbek, „Świat Motoryzacji”, 4/2005, s. 14). W ostatnich latach zwiększa się liczba serwisów zdobywających certyfikaty, ubiegających się o autoryzację i wdrażających systemy jakości. Autoryzacja jest przepustką do zdobywania klientów flotowych. W ich opinii oznacza ona gwarancję standardu usług, za którą odpowiedzialność ponosi częściowo także producent samochodów.

Warsztaty nieposiadające wystarczających środków na wdrażanie kosztownych innowacji technologicznych i produktowych częściej rozpoczynają wprowadzanie innowacji organizacyjnych. Potwierdza to w swoich badaniach A. Żołnierski. W latach 2003 i 2004 serwisy motoryzacyjne wprowadziły $20,5 \%$ innowacji w zakresie organizacji i zarządzania warsztatem i 19,5\% innowacji produktowych; najmniej było innowacji ekologicznych (5\%).

Ryc. 3. Udział warsztatów samochodowych wdrażających innowacje w ogólnej liczbie warsztatów samochodowych

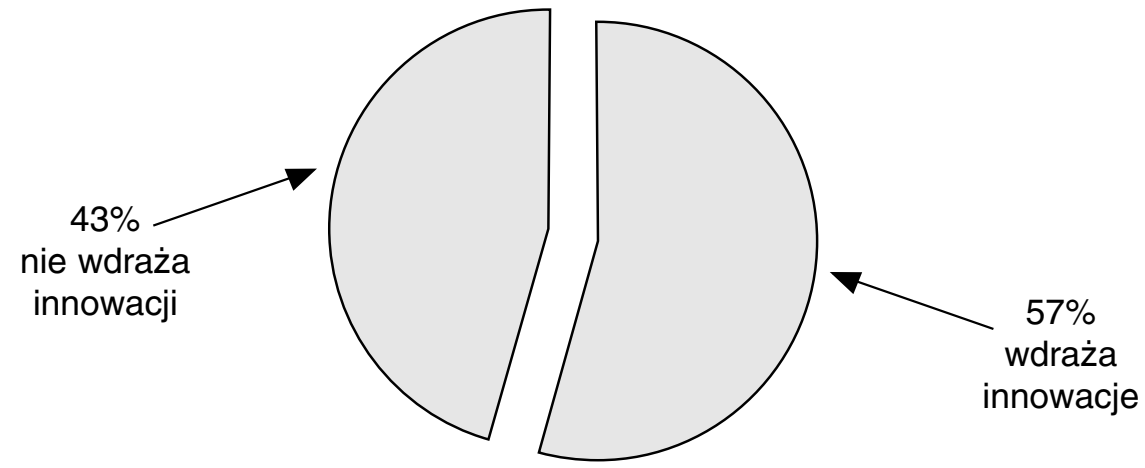

Źródło: opracowanie na podstawie badań własnych 
Ryc. 4. Rodzaje innowacji wprowadzanych przez warsztaty w latach 2003 i 2004

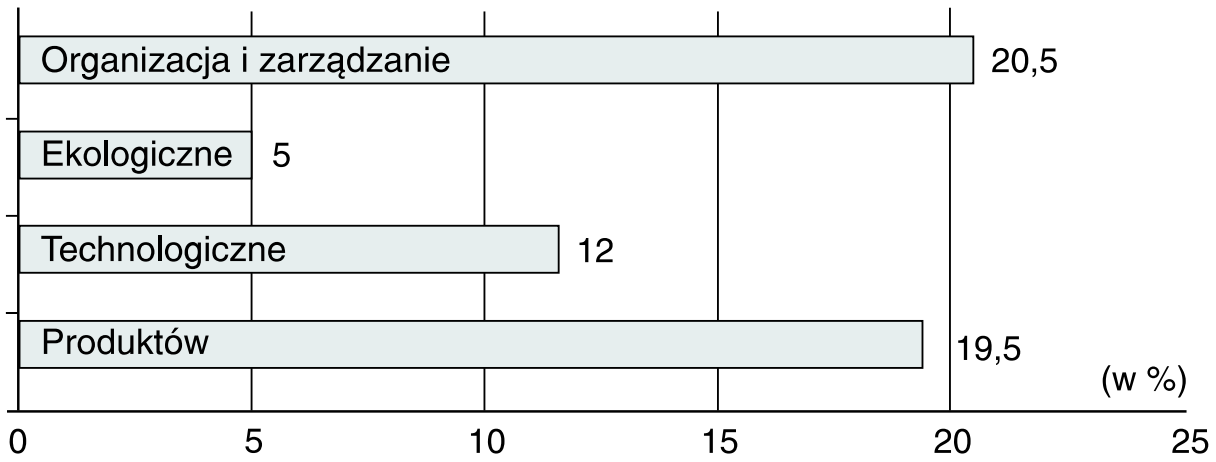

Źródło: opracowanie na podstawie badań własnych

\section{Zachowania innowacyjne - na przykładzie usługowych firm motoryzacyjnych}

Usługi motoryzacyjne przeważnie są świadczone przez mikrofirmy, które cechuje niewielka liczba innowacji. Firmy te można scharakteryzować za pomocą analizy mocnych i słabych stron lub poprzez ocenę zachowań innowacyjnych. Analiza S-W przykładowej firmy usługowej z branży motoryzacyjnej została przedstawiona w tab. 5. Wynika z niej, że zaletą małych firm wprowadzających innowacje są przede wszystkim czynniki o charakterze behawioralnym, a ograniczenia procesów innowacyjnych związane są głównie z czynnikami materialnymi (Stawasz, 1999, s. 54).

Tab. 5. Mocne i słabe strony firm o małej skali w dziedzinie innowacji

\begin{tabular}{|c|c|}
\hline Mocne strony & Słabe strony \\
\hline - Mała biurokracja, szybkie reakcje na nowe okazje, & - Brak formalnych umiejętności zarządzania fir- \\
skłonność do ryzyka, elastyczność, specjalizacja & ma, strategia przetrwania, niewielkie potrzeby \\
- Proste struktury firmy, nieformalne sieci w ko- & właściciela-menedżera, który nie radzi sobie \\
munikacji wewnątrz firmy i na zewnatrz & z coraz bardziej złożonymi problemami firmy, \\
- Kadra techniczna może z powodzeniem zajmo- & zarządzanie intuicyjne \\
wać się kilkoma różnymi działaniami w firmie; & - Niewielkie zasoby, brak czasu i wiedzy do two- \\
możliwy bezpośredni nadzór menedżera nad pra- & rzenia zewnętrznych sieci wspomagających \\
cownikami, w większości oparty na zaufaniu & działalność naukowo-techniczną \\
- Działanie w wąskich niszach rynkowych, łatwośćc & - Brak wysoko wykwalifikowanych specjalistów \\
dostosowania się do zmiennych potrzeb klientów & technicznych, są zbyt kosztowni dla firmy \\
- Łatwość wdrażania wszelkich zmian niewyma- & - Trudności z wyjściem poza rynek lokalny \\
gających nakładów finansowych, właściciele- & - Trudności w dostępie do zewnętrznego kapita- \\
-menedżerowie są zwykle otwarci na wszelkie & łu na finansowanie innowacji, niewielkie zaso- \\
pomysły usprawniające działalność firm & by firm i niska zdolność do ponoszenia kosz- \\
- Rządowe programy wspierania biznesu nakie- & tów ryzyka innowacji \\
rowane są na innowacyjność małych firm, & - Utrudniony dostęp do programów wsparcia ze \\
a regulacje niekiedy są w stosunku do nich sto- & względu na koszty uczestnictwa, brak wiedzy, trud- \\
sowane mniej rygorystyczni & ności z przygotowaniem wniosków o wsparcie \\
- Duża atrakcyjność dla współpracy z dużymi & - Słaba pozycja we współpracy z dużymi firma- \\
firmami & mi, niechęć do współpracy z konkurencją \\
- Zdolność do szybkiego uczenia się i wykorzy- & - Brak czasu na dokształcanie się, zajmowanie się \\
stywania wiedzy w działalności firmy & wszystkimi sprawami firmy \\
\hline
\end{tabular}

Źródło: opracowanie własne na podstawie: E. Stawasz, 1999, s. 54-56. 
Zachowania innowacyjne można analizować, opierając się na taksonomii Rizzoniego ${ }^{2}$, który wyodrębnia sześć rodzajów małych firm uszeregowanych według stopnia innowacyjności (od najmniej do najbardziej innowacyjnej): firmy statyczne (konserwatywne), tradycyjne, zdominowane, imitujące, oparte na technologii i oparte na nowej technologii. Uszeregowanie to Rizzoni opisał funkcją kilku charakterystycznych czynników wpływających na zachowania innowacyjne firm. Badania własne warsztatów zajmujących się obsługą i naprawą samochodów potwierdzają zgodność zachowań innowacyjnych dla pierwszych czterech stopni taksonomii Rizzoniego (tab. 6).

Tab. 6. Niektóre zachowania innowacyjne warsztatów samochodowych

\begin{tabular}{|l|l|c|}
\hline \multicolumn{1}{|c|}{ Firmy } & \multicolumn{1}{|c|}{ Zachowania innowacyjne } & Udział w \% \\
\hline Imitujące & $\begin{array}{l}\text { Specjalizacja, systemy jakości, nabywanie know-how, pozyskiwanie pra- } \\
\text { cowników, skomplikowane technologie }\end{array}$ & 10 \\
\hline $\begin{array}{l}\text { Zdomino- } \\
\text { wane }\end{array}$ & $\begin{array}{l}\text { Specjalizacja, pozyskiwanie pracowników, współpraca sieciowa, współ- } \\
\text { praca z dużymi firmami }\end{array}$ & 20 \\
\hline Tradycyjne & $\begin{array}{l}\text { Wzbogacanie narzędzi i wyposażenia, modyfikacje w produkcie, do- } \\
\text { skonalenie procedur, sporadyczna współpraca sieciowa, innowacje przy- } \\
\text { chodzą z zewnątrz, elastyczność, technologie mało intensywne kapita- } \\
\text { łowo }\end{array}$ & 30 \\
\hline $\begin{array}{l}\text { Konserwa- } \\
\text { tywne }\end{array}$ & $\begin{array}{l}\text { Przetrwanie, bez wzrostu, tylko zakupy niezbędnych narzędzi, drobne } \\
\text { usprawnienia, stare i proste technologie bazujące na pracy, niskie kosz- } \\
\text { ty - przede wszystkim pracy, duże doświadczenie rzemieślnicze }\end{array}$ & 40 \\
\hline
\end{tabular}

Źródło: opracowanie własne na podstawie: A. Rizzoni, Technological Innovation and Small Firms: A Taxonomy, „International Small Business Journal”, 1991, vol. 9 [w:] E. Stawasz, Innowacje a mała firma, Wydawnictwo UŁ, Łódź 1999, s. 54-56.

\section{Cechy innowacyjnego serwisu motoryzacyjnego}

Opierając się na prezentowanych przykładach wdrożeń innowacji, można wskazać istotne cechy innowacyjnego warsztatu naprawczego w branży samochodowej.

Warsztat innowacyjny:

- systematycznie poszerza zakres świadczonych usług i obszar swego działania;

- jest zorientowany marketingowo;

- podejmuje walkę konkurencyjną na rynku;

- stale unowocześnia asortyment usług, narzędzi i wyposażenia;

- doskonali procesy we wszystkich obszarach działalności;

- korzysta z regenerowanych części lub sam je regeneruje;

- wykorzystuje technologie informatyczne;

- dysponuje odpowiednią strategią marketingową;

- stymuluje kreatywność pracowników w zakresie innowacji;

- doskonali wiedzę.

${ }^{2}$ A. Rizzoni, Technological Innovation and Small Firms: A Taxonomy, „International Small Business Journal", 1991, vol. 9. [w:] E. Stawasz, Innowacje a mała firma, UŁ, Łódź 1999, s. 54-56. 
Tab. 7. Cechy innowacyjnego serwisu samochodowego

\begin{tabular}{|l|l|}
\hline \multicolumn{1}{|c|}{ Kryteria } & \multicolumn{1}{c|}{ Cechy } \\
\hline Produkt & $\begin{array}{l}\text { Stale poszerza zakres świadczonych usług i obszar działania firmy, tworzy lub } \\
\text { kopiuje nowe usługi, jest zorientowany na klienta, rozwiązuje nawet jego niety- } \\
\text { powe potrzeby, drobne usługi świadczy bezpłatnie (kontrola, diagnostyka, wy- } \\
\text { cena, pompowanie kół itp.), wymusza na konkurencji swoisty wyścig w zakresie, } \\
\text { ilości i jakości usług. }\end{array}$ \\
\hline Technologia & $\begin{array}{l}\text { Wzbogaca i unowocześnia asortyment narzędzi i wyposażenia, doskonali } \\
\text { procesy. }\end{array}$ \\
\hline Ekologia & $\begin{array}{l}\text { Wykorzystuje regenerowane części i zespoły, wprowadza i stosuje środki obo- } \\
\text { jętne lub łatwo przyswajalne dla środowiska. }\end{array}$ \\
\hline Zarządzanie & $\begin{array}{l}\text { Współpracuje z innymi, wchodzi w powiązania sieciowe, wykorzystuje zdoby- } \\
\text { cze techniki informatycznej, stale podnosi poziom kwalifikacji kadry, ma wizję } \\
\text { kierunków rozwoju, planuje działania i dysponuje odpowiednią strategia, stosu- } \\
\text { je motywacyjny system wynagradzania, premiujący kreatywność pracowników, } \\
\text { odbywa się w nim dobra komunikacja z pracownikami. }\end{array}$ \\
\hline
\end{tabular}

Źródło: opracowanie własne

\section{Podsumowanie}

Na podstawie badań sektora małych zakładów naprawczych samochodów można stwierdzić, że większość z nich stara się wprowadzać innowacje. Są to innowacje produktowe, technologiczne, organizacyjne, przy czym większość wykazuje cechy innowacji ekologicznych. Takie trendy w sektorze mogą być wynikiem zarówno zmiany świadomości innowacyjnej przedsiębiorców, jak i podniesienia poziomu wiedzy. Innowacje są rozumiane jako narzędzie przedsiębiorczości i ważny element walki konkurencyjnej. Wyraźnie zaznacza się również zmiana orientacji przedsiębiorstw - na orientację marketingową - co także jest wynikiem przepływu wiedzy i wdrażania innowacji.

\section{Literatura}

1. Chłopek Z., Ochrona środowiska naturalnego, WKiŁ, Warszawa 2002.

2. Drucker P.F., Innowacje i przedsiębiorczość, Praktyka i zasady, PWE, Warszawa 1992.

3. Gołąbek T., Próba bilansu - rozmowa z Alfredem Franke, analitykiem rynku motoryzacyjnego, „Świat Motoryzacji”, 4/2005, s. 14.

4. Kelar Ł., Lakiernicza rewolucja, „Świat Motoryzacji”, 9/2004, s. 36.

5. Kelar Ł., W lakiernictwie czas ciagtych zmian, „Świat Motoryzacji”, 3/2005, s. 34.

6. Konieczny M., 100 pytań o GVO, PIM Consulting, Warszawa 2004.

7. Majchrzak M., Od kabiny do kabiny, „Świat Motoryzacji”, 3/2005, s. 36.

8. Majchrzak M., Postępowo w lakiernictwie, „Świat Motoryzacji”, 12/2003, s. 28 i 29.

9. Majchrzak M., Renowacja lakierów samochodowych, „Świat Motoryzacji”, 4/2005, s. 36.

10. Majchrzak M., W zgodzie z ekologia, „Świat Motoryzacji”, 6/2004, s. 46-48.

11. Marciniak S., (red.), Makro i mikroekonomia. Podstawowe problemy, Wydawnictwo Naukowe PWN, Warszawa 1998.

12. Pomykalski A., Zarzqdzanie innowacjami, PWN, Warszawa-Łódź 2001.

13. Schumpeter J., Teoria rozwoju gospodarczego, PWN, Warszawa 1960. 
14. Sklorz A. R., Nadchodzi nowa era, „Świat Motoryzacji”, 9/2004, s. 38 i 39.

15. Sklorz A. R., Scenariusze wydarzeń, „Świat Motoryzacji”, 6/2004, s. 40 i 41.

16. Stawasz E., Innowacje a mała firma, UŁ, Łódź 1999.

17. Strategie innowacji, konferencja zorganizowana przez Katedrę Teorii i Zarządzania SGH, 4.11.2003 r., http://akson.sgh.waw.pl/innowacje/badanie_wyniki.htm, 11.05.2005 r.

18. Szreter P., Praktyki serwisowe polskiej branży flotowej, „Flota Autobiznes”, 4/2004, s. 23 i 24.

19. Włodarczyk M., Janczewski J., Wykorzystanie możliwości recyklingu jako działanie przedsiębiorcze w ustugach motoryzacyjnych, ,Przegląd Organizacji”, 1/2005, s. 23 i 24.

20. Żołnierski A., Innowacyjność polskich mikro przedsiębiorstw, Warszawa 2005, www.parp.gov.pl/pe_badania.php, 7.09.2005 r.

21. Żołnierski A., Potencjat innowacyjny polskich matych i średniej wielkości przedsiębiorstw, Warszawa 2005, www.parp.gov.pl/pe_badania.php, 7.09.2005 r.

\section{Automotive Services as an Exemplification of Small Company with Innovation as an Instrument of Entrepreneurship}

The article present the subject of innovation as an instrument of entrepreneurship in small company from automotive service business. An innovation is defined as a change that creates new value for the enterprise and customers. In small automotive companies, innovations of endproduct, technology, ecology and management, are included. The product innovation is connected to the technological changes, because garage service needs to buy new equipment to increase range of its service. The ecological innovation leads to better protection of the environment. The innovation in management, in all the company or its part, is the most important. It applies to planning, organization, management, control and communication. The research shows that innovations are accepted in service garage broadly. It is result of a change in entrepreneur's attitude to innovation, and of his better knowledge. The car mechanic must constantly update his knowledge or he would not be able to repair modern car. The innovation is his strong instrument of entrepreneurship and important component of the power of his competition, because he can not repair contemporary car. The innovation are his strong instrument of entrepreneurship and important component of competition. 